DIW BERLIN

Discussion Papers

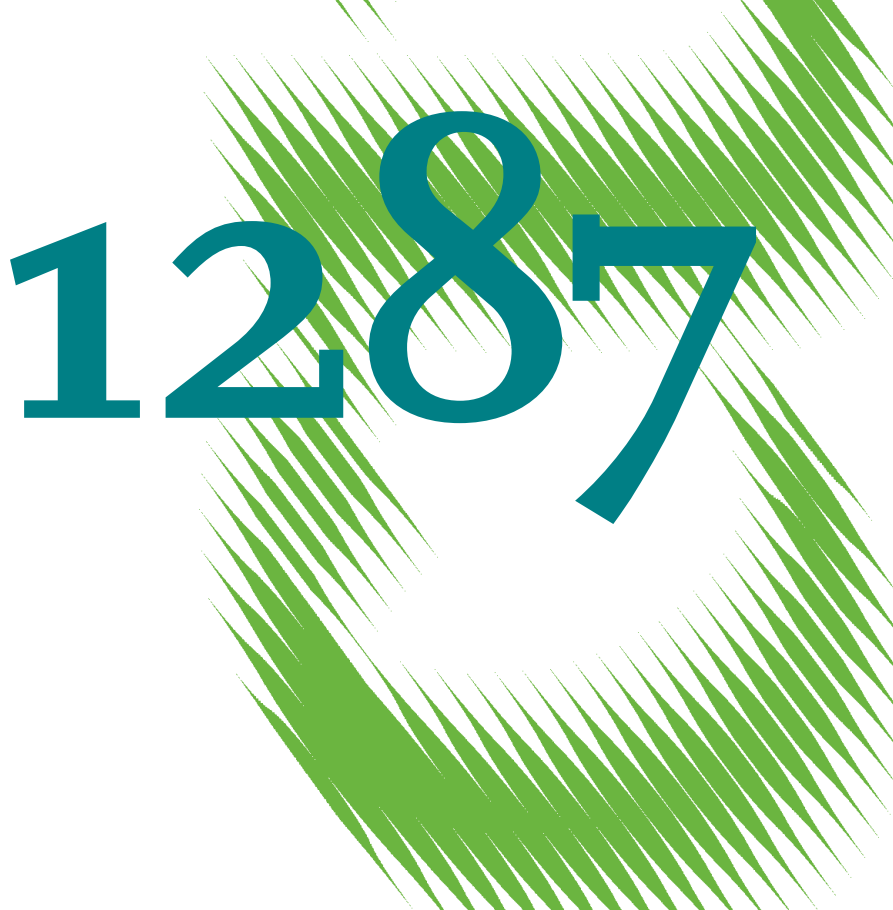

Dynamics and Drivers of Consumption and Multidimensional Poverty

Evidence from Rural Ethiopia 
Opinions expressed in this paper are those of the author(s) and do not necessarily reflect views of the institute.

IMPRESSUM

(C) DIW Berlin, 2013

DIW Berlin

German Institute for Economic Research

Mohrenstr. 58

10117 Berlin

Tel. $+49(30) 89789-0$

Fax +49 (30) $89789-200$

http://www.diw.de

ISSN print edition $1433-0210$

ISSN electronic edition 1619-4535

Papers can be downloaded free of charge from the DIW Berlin website:

http://www.diw.de/discussionpapers

Discussion Papers of DIW Berlin are indexed in RePEc and SSRN:

http://ideas.repec.org/s/diw/diwwpp.html

http://www.ssrn.com/link/DIW-Berlin-German-Inst-Econ-Res.html 


\title{
Dynamics and drivers of consumption and multidimensional poverty: Evidence from rural Ethiopia
}

\author{
Tilman Brück and Sindu Workneh Kebede
}

\begin{abstract}
This study aims to explore poverty measures, its dynamics and determinants using Multidimensional Poverty Index (MPI) and consumption poverty. Our results show that the two measures assign similar poverty status to about 52 percent of households and that both approaches confirm poverty is mainly transient in rural Ethiopia. However, we find that the trend in adjusted head count poverty is different when using these two poverty measures. In terms of determinants of poverty dynamics, we find that household size matters in consumption poverty while we do not find significant effects on multidimensional poverty. Amongst the shocks, drought shock is found to affect consumption poverty but not multidimensional poverty. This implies that short-term shocks are more reflected in consumption poverty while the effect of simultaneous shocks is exhibited significantly on multidimensional poverty. Overall, our result provides empirical evidence on the importance of using both measures as complementary to get a full picture of poverty measure, dynamics and determinants.
\end{abstract}

Keywords: poverty dynamics, consumption, multidimensional poverty index, rural Ethiopia.

JEL Classification: 132, 012

Affiliations: Tilman Brück: IZA and SIPRI;

Sindu Workneh Kebede: Graduate Center, DIW Berlin and Humboldt University of Berlin. Corresponding author: Sindu Workneh Kebede, email: skebede@diw.de; Mohrenstr. 58, 10117 Berlin, Germany; phone: +49 3089789425.

Acknowledgments: We thank colleagues at the Development and Security Department of DIW Berlin for valuable comments: Ghassan N. Baliki, Nathan Fiala, Neil Ferguson, Olaf de Groot, Veronika Hümmer, Damir Esenaliev, Antje Kröger, Nina Wald, Tony Muhumuza, Kati Schindler, Susan Steiner, and Marc Vothknecht as well as Muluken Elias Adamseged for his constructive comments and contributions. Sindu would like to thank the Klimafolgenforschung der Humboldt-Universitäts-Gesellschaft for the financial support during her doctoral studies. 


\section{Introduction}

This study aims to contribute to the existing literature on poverty measure and its dynamics using the adjusted class of poverty measures proposed by Alkire and Foster (2011) and by comparing these with consumption poverty measure. We explore this comparison in a dynamic context using data from rural Ethiopia. In addition, we analyze the determinants of poverty dynamics using these two measures and assess the effect of shocks and socioeconomic factors on poverty dynamics.

There is a well-established literature on poverty dynamics (Baulch and Hoddinott, 2000) and its determinants in developing countries (Haddad and Ahmed, 2002; Hulme and Shepherd, 2003; Mckay and Lawson, 2003; Dercon and Krishnan, 2000; Swanepoel, 2005; Bigsten and Shimeles, 2008). A review of studies on the dynamics of poverty in developing countries, by Baulch and Hoddinott (2000), shows that a large proportion is transient. The review finds that the percentage of households experiencing poverty for one or two time periods is always greater than those households that are 'always poor'. In Ethiopia, for instance, Dercon and Krishnan (2000) find that over 30 percent of rural households are sometimes poor compared to the 24.8 percent that are 'always poor'.

Swanepoel (2005) uses the Ethiopian Rural Household Survey (ERHS) from 1994-1997 to analyze poverty dynamics in rural Ethiopia. Using consumption expenditure as a measure of poverty, Swanepoel finds that movements of households into poverty are associated with life cycle effects and incidence of crop failures, while movements out of poverty are related to smaller household size. The study finds that transiently poor households have a higher dependency ratio, face more frequent crop failures, and have smaller areas of land available for cultivation. In contrast, chronically poor households own fewer assets and earn less from the sale of livestock. A study by Bigsten et al. (2003), using the same panel survey, finds that cultivation of Khat ${ }^{1}$, a new export cash crop, decreases the probability of households falling into poverty while increasing the chance of escaping poverty in rural areas.

\footnotetext{
${ }^{1}$ Khat/ qat contains the alkaloid called cathinone, an amphetamine-like stimulant that is said to cause excitement, euphoria and loss of appetite. It is an illegal drug in many countries.
} 
Bigsten and Shimeles (2008) use a panel of 10 years (1994-2004) to analyze poverty transition and persistence in Ethiopia. The study uses consumption expenditure to measure poverty and the spells approach ${ }^{2}$ to analyze poverty dynamics. They find that there is a higher probability (61 percent) of poverty transition of both movements into and out of poverty in rural areas. However, they find substantial persistence of both poverty and nonpoverty; in that it is harder to get out of poverty once in it, and it is less probable to re-enter poverty once one has escaped from it. The study shows that household size, primary education of the household head/spouse, access to markets, as well as changes in rainfall levels and variability are prominent factors in both facilitating exit out of poverty and preventing re-entry into poverty across rural areas.

Even if the availability of panel datasets enables the investigation of poverty dynamics, most studies use consumption expenditure or income to measure poverty dynamics. However, income and consumption tend to fluctuate over time and are prone to measurement errors (Hulme and Shepherd, 2003). Measurement errors in consumption expenditure arise not just from the intrinsic difficulty of calculating prices and consumption quantities, but also from the recall error that induces a downward bias in the estimation (Dinkelman, 2004). Moreover, in panel datasets, such measurement errors are especially problematic since the values are miscalculated in every round of survey (Baulch and Hoddinott, 2000). One way to overcome this problem is to use asset and multidimensional poverty indices (Hulme and Shepherd, 2003; Sahn and Stifel, 2000) to study poverty and its dynamics.

In line with this, research on poverty measures has reached consensus that poverty is multidimensional and hence, its measurement has to reflect this character. Multi-dimensional poverty measures, composed of variables such as literacy or tangible assets, are much more reasonable methods of poverty assessment and are more likely to capture long-term poverty (Hulme and Shepherd, 2003). Accordingly, studies that use diverse indicators to measure poverty and subsequently compare it with consumption or monetary measures have emerged. Findings of this research indicate that different methods of poverty measurement in developing countries often lead to different findings (Davis and Baulch, 2011; Chambers, 1997; Laderchi et al., 2003; McGee, 2004; Stewart et al., 2007). For instance, a study by

\footnotetext{
2 The spells approach focuses on probabilities of ending poverty or a non-poverty spell (for details see, Bane and Ellwood, 1986; Devicienti, 2003; and Stevens, 1999).
} 
Laderchi et al. (2003) finds that there is significant lack of overlap between the different poverty measuring methods with, for example, nearly half the Peruvian or Indian population identified as being poor using monetary measure are not identified as having capability poverty.

Some studies examine how poverty dynamics and multidimensional poverty measures interact (Davis and Baulch, 2011). Davis and Baulch (2011) find that while expenditurebased poverty measures are common, the shortcomings of these measures are magnified in studies of poverty dynamics. They find that adding asset-based measures improves the assessment of poverty transition and dynamics in Bangladesh, thus confirming the suggestion that expenditure-based measures should be supplemented by asset measures in poverty dynamics. However, studies in the area of comparing different poverty measures in a dynamic context are scarce, especially in developing countries.

Our hypothesis in assessing poverty dynamics using both measures is that it is important to combine both consumption-based measure of poverty with multidimensional measure of poverty in order to obtain a full picture of poverty. We believe that having a poverty measure that combines short-term fluctuations (measured by consumption expenditure) and long-term poverty (measured by multidimensional poverty measure) is important for understanding the entirety of poverty. In particular, our study draws renewed attention to the need to assess poverty dynamics when recommending viable policy options. For instance, in situations where chronic poverty is prevalent, the policy recommendation is more of asset creation and distribution as well as the provision of basic physical and human capital infrastructure. In contrast, for transient poverty policies that promote provision of safety nets, coping mechanisms, and income transfers that reduce vulnerability to shocks and assist households to return back to better-off status are prescribed (Baulch and Hoddinott, 2000; World Bank, 2001). Accordingly, it is important to identify which shocks affect the transient poor, when using different welfare indicators, in order to design more effective and robust safety nets. This study is motivated by the above considerations.

Consequently, we explore the dynamics of poverty using both consumption and multidimensional indices and distinguish between chronic and transient poverty. Specifically, our study uses an innovative approach of measuring poverty using a multidimensional 
poverty index constructed from a combination of indicators; namely education, health, and living standards to address two research questions. First, does the trend in poverty dynamics differ when using multidimensional index as a welfare indicator as compared to consumption expenditure? Secondly, how do the socio-economic determinants and shocks affect poverty dynamics differently when using these different welfare indicators?

The results show that the two measures assign similar poverty status to about 52 percent of households. We find that the trend in adjusted head count poverty ratio is different when using these two poverty measures. However, both approaches confirm that poverty is mainly transient in Ethiopia. In terms of determinants, household size is found to have significant effect on consumption poverty while the effect on multidimensional poverty is not significant. Drought shocks are found to affect consumption poverty but not multidimensional poverty. However, the effect of simultaneous shocks is significantly reflected on multidimensional poverty.

The rest of the paper is organized as follows. The next section outlines the conceptual framework for measuring poverty using consumption aggregates and multidimensional indicators. Section three discusses the data set used and the methodology in detail including the choice of indicators for the multidimensional poverty measure. In section four, we describe the results on poverty dynamics comparing consumption poverty with multidimensional poverty and an overview of shocks faced by sample households. Section five presents the econometric results on the determinants of poverty dynamics with a focus on shocks and a comparison of results for consumption and multidimensional poverty measures. Finally, section six concludes.

\section{Conceptual framework}

\subsection{Consumption poverty measure}

The Foster-Greer-Thorbecke Index (FGT, 1984) is a commonly used measure of poverty. It comprises the most desirable properties of a poverty index, such as decomposition and subgroup consistency. 
The FGT index is defined as:

$$
P_{\alpha}=\frac{1}{n} \sum_{i}^{q}\left(\frac{z-y_{i}}{z}\right)^{\alpha}, \alpha \geq 0 \text { for } Y \leq Z
$$

Where $P_{\alpha}$ is a measure of poverty, $z$ is the poverty line (in terms of consumption expenditure), $n$ is total population, $q$ is total number of poor households, and $Y$ is the total consumption expenditure. The poverty index, $P_{\alpha}$ changes when $\alpha$ takes different values. For instance, when $\alpha$ is 0,1 , and $2, P_{\alpha}$ equals the head count index $\left(P_{0}\right)$, the poverty gap index $\left(P_{1}\right)$, and the poverty severity measure $\left(P_{2}\right)$, respectively. In this study, the FGT indices of poverty are used as comparative poverty measures to the MPI. ${ }^{3}$

Consumption aggregates are calculated as the sum of food and non-food consumption expenditures. Food consumption is the sum of all food items consumed in the last week, including purchased (both raw cereals and prepared meals), from own stock, gifts and foodfor-work in kind payments, scaled to a month by multiplying it by 4.28 (Dercon and Hoddinott, 2004). These consumption levels are calculated using prices obtained from local markets during the household surveys. Non-food consumption includes direct consumables such as matches, soap, linen and clothes. Expenditures on durables and non-durables and on schools, health, taxes and extraordinary contributions are excluded due to heterogeneity in responses in terms of these expenditures (see Dercon et al., 2009 for details). Total consumption expenditure is then calculated as the sum of food and non-food consumption, and is deflated by the 1994 prices (base year) in order to find real total consumption expenditure. Finally, the real consumption expenditure is divided by household size to obtain real consumption per capita expenditure. Following Dercon et al. (2009), a poverty line

\footnotetext{
${ }^{3}$ Most studies on developing countries use consumption rather than income for reasons of under-reporting (or misreporting). It is a better indicator of long-term average well-being because consumption shows what is in fact consumed instead of ability to purchase as in the case of income (Fields (1983); Ravallion (1991); Bigsten et al. (2003)).
} 
calculated using real consumption per capita expenditure is utilized to identify households as poor and non-poor. ${ }^{4}$

\subsection{Multidimensional poverty measure ${ }^{5}$}

An extensive debate on the concept of poverty measurement was raised after Amartya Sen's seminal work on poverty, famines, entitlements and deprivations (Sen, 1976; 1981; 1985). Sen (1985) defines poverty as lack of capability, where capability is defined as being able to live longer, to be well-nourished, healthy, and literate. This definition sets the basic grounds for the establishment of multidimensional poverty measures, which subsequently led to the development of various approaches and indices (such as asset-based approach and multidimensional poverty index) to capture poverty.

The basic idea of Multidimensional poverty index (MPI) is that the well-being of a household/individual depends not just on income or consumption, but also on several other dimensions or capabilities such as health, education, and standard of living (including assets and housing quality). The multi-dimensional poverty measure is more likely to underpin long-term poverty, whereby variables such as literacy or tangible assets are much more reasonable methods of poverty assessment (Hulme and Shepherd, 2003). In addition, consumption expenditure, as a flow variable, is more likely to capture mobility of households in to and out of poverty while the MPI poverty indices capture long-term well-being.

Bourguignon and Chakravarty (2003, pp.27) state that, “... a multidimensional approach to poverty defines poverty as a shortfall from a threshold on each dimension of an individual's well-being." Following this definition, a plausible strategy to identify the poor is to compare each individual's achievements against the respective dimension-specific cutoffs and by looking at achievements across dimensions in order to arrive at complete specification of an identification method. Two commonly used identification criterion in MPI are the union and the intersection approaches. In the union approach, an individual or household is said to be multi-dimensionally poor if there is at least one dimension in which the person is deprived. The weakness of this approach is that when the number of dimensions is large, it will identify most of the population as being poor (Alkire and Foster, 2011). On the other hand,

${ }^{4}$ For details on calculation of consumption aggregates and poverty line, see Dercon et al. (2009).

${ }^{5}$ Part of this section is drawn from Alkire and Foster (2011). 
the intersection approach identifies a person as being poor only if the person is deprived in all dimensions. This approach, however, misses people who are experiencing extensive, but not universal deprivation.

An alternative and plausible approach uses an intermediate cutoff level that lies between these two extremes (Alkire and Foster, 2011). An individual is identified as deprived when the number of dimensions in which the person is deprived is at least above some minimum cutoff number of dimensions (k). If the number of deprived dimensions falls below the cutoff $k$, then the person is not considered poor. This method of identification is referred to as the dual cutoff since it depends on both the within dimension cutoffs to determine whether a person is deprived in that dimension and across dimension cutoffs to identify the poor by 'counting' the dimensions in which a person is deprived.

Following the theoretical work of Alkire and Foster (2011), we assume an identification function $\rho\left(x_{i j}, z_{j}\right)$, where $x_{i j}$ is $n x d$ matrix of indicators such that $i=1,2 \ldots n$ denotes the number of individuals with deprivation and $j=1,2 \ldots d$ denotes the number of deprivation dimensions. $z_{j}$ is a row vector of dimension specific cut-offs. It reflects the cut-off point below which a person is considered to be deprived in dimension $j$. The dual cut-off $(k)$ is then used to finalize the identification process of the poor by counting the number of indicators a person is deprived in. The next step in poverty measure is aggregation. In poverty aggregation, we calculate the head count ratio $H=q / n$; where $q=\sum_{i=1}^{n} \rho_{k}\left(x_{i}, z\right)$ denotes the number of poor identified using the dual cut-off approach and $n$ is the total population.

However, as described in the poverty measurement literature, the head count ratio $(H)$ has its drawbacks since it violates the 'dimensional monotonicity' and sub-group consistency conditions, ${ }^{6}$ both of which are crucial to any poverty measurement exercise. To resolve this problem, Alkire and Foster (2011) include additional information on the breadth of deprivation experienced by the poor. They define the censored vector of deprivation

${ }^{6}$ Dimensional monotonicity states that if a poor person becomes newly deprived in an additional dimension, then the overall poverty should increase and sub-group consistency states that the measure must be disaggregated to show how much each dimension contributes to poverty. 
counts $C_{i}(k)=\sum_{i=1}^{n} c_{i} \rho_{k}\left(x_{i}, z\right)$, for $i=1,2 \ldots n$. Here, $C_{i}(k) / d$ represents the share of deprivations experienced by a poor person $i$. Hence, the average deprivation share across the poor is given by $A=C_{i}(k) / q d$. The average deprivation share $(A)$ - also called as average poverty or poverty intensity - gives the fraction of possible dimensions $d$ in which the average poor person endures deprivation.

Finally, the combination of the head count ratio $(H)$ and the poverty intensity $(A)$ gives the multidimensional poverty measure $M_{0}=H A$. The multidimensional poverty measure $\left(M_{0}\right)$, also known as the adjusted head count ratio, combines information on the prevalence of poverty and the average extent of a poor person's deprivation. Hence, we calculate $M_{0}$ as follows:

$$
M_{0}=\frac{1}{n d} \sum_{i=1}^{n} c_{i} \rho_{k}\left(x_{i}, z\right)
$$

Where $n$ is the total population, $d$ is the number of dimensions, $z$ is the thresholds vector, $k$ is the cutoff, and $\rho_{k}\left(x_{i}, z\right)$ is the identification function.

\section{Data and methodology}

\subsection{Data}

This study uses the longitudinal Ethiopian Rural Household Survey (ERHS), collected by the Addis Ababa University Department of Economics. ERHS is collected in collaboration with the Center for Study of African Economies (CSAE) at the University of Oxford and the International Food Policy Research Institute (IFPRI). Data collection started in 1989 during which IFPRI conducted a survey of 6 Peasant Associations ${ }^{7}$ located in the Ambara, Oromia, and the Southern Nations Nationalities People's (SNNPR) regions. Civil conflict prevented survey work from being undertaken in Tigray region. The survey collected consumption, asset, and income data from about 450 households.

\footnotetext{
${ }^{7}$ Peasant associations are the lowest administrative unit consisting of a number of villages.
} 
In 1994, the survey was expanded to cover 15 villages across the country and increased the sample size to 1477 households. The nine additional communities were selected in order to account for the diversity of the farming systems in the country. From the original 1989 sample, about 360 households were successfully traced and re-interviewed (Dercon and Hoddinott, 2004). Further rounds of the ERHS were conducted in 1995, 1997, 1999, 2004 and 2009. Population shares in the survey are consistent with the population shares in the three main sedentary farming systems namely: (1) plough-based cereal farming systems of the Northern and Central Highlands; (2) mixed plough/hoe cereal farming systems; and (3) hoe-culture complex farming systems based around enset (false banana).

According to Dercon et al. (2011), sample attrition between 1994 and 2009 is low due to the institutional continuity in the organization of data collection. Over the 15-year period, only $16.1 \%$ of sample households were lost with $1.1 \%$ of attrition per year. A study by Dercon et al. (2009) found that sample attrition over the period 1994-2004 was random. They found that the mean values for households exiting the sample and staying in the sample were not statistically different in terms of initial levels of characteristics of household head (age and sex), assets (fertile land, all land holdings, and cattle), or consumption. However, they found that exiting households, at baseline, were smaller than those not exiting. Survey rounds in 2004 and in 2009 had low attrition rate of less than 0.6\% per year (Dercon et al., 2011).

For this study, we use the 1994, 2004 and 2009 survey rounds. These survey rounds are chosen due to the consistency and data availability for the MPI indicators. It should be noted that the ERHS dataset is not nationally representative because the sample excludes pastoral households, urban areas, and covers only 15 villages. However, it gives a good picture of major farming systems in the highlands of Ethiopia (Dercon and Hoddinott, 2004) and suffices to depict the general overview of rural non-pastoral livelihoods in Ethiopia.

\subsection{Multidimensional poverty measure: dimensions and indicators}

Following the conceptual framework presented in section 2, we calculate poverty using two approaches. One uses the FGT approach and consumption expenditure as a measure of welfare as given in equation (1). The other uses multidimensional approach to calculate the adjusted headcount ratio $\left(M_{0}\right)$ given in equation (2). To calculate the multidimensional 
adjusted headcount ratio, we follow Alkire and Santos (2010) and use similar dimensions, fitted to the peculiarities and specifics of rural Ethiopia and the indicators that are available in the survey across rounds.

Alkire and Santos (2010) extensively discuss the choice of dimensions for a multidimensional poverty measure. They follow Sen's argument that the choice of relevant functionings and capabilities for any poverty measure is a value judgment rather than a technical exercise. Alkire and Santos suggest a broad list of dimensions to be included in a measure of poverty namely health, education, standard of living, empowerment, work, environment, safety from violence, social relationships, and culture. Our study uses three of the dimensions namely health, education and living standard as dimensions of poverty measure due to data availability. The household is chosen as the unit of analysis since data on most indicators is only available at the household level.

The choice of indicators within dimensions is based on Alkire and Santos (2010) and participatory poverty assessment of Ethiopia (MoFED, 2005) to fit the rural context of Ethiopia. Alkire and Santos (2010) use child mortality and nutrition as main indicators of health. In our study, child mortality and adult illness (morbidity) are used as indicators of health (Table 1). This is chosen due to lack of data on nutrition in the 2009 round of ERHS. A household is taken as deprived in child mortality if at least one child death (child aged between $0-18$ years) is observed in the household in the past five years prior to the survey. Similarly, if a household reports the illness of adult member during the four weeks prior to the survey, the household is taken as deprived in adult illness (morbidity). Unfortunately, there is no information about the severity of the illness or how often it occurred. However, we believe that including this indicator together with child mortality gives a balanced assessment of health in the household. The inclusion of morbidity is justified by Sen (1996), who argues that in developing economies, where extreme poverty prevails, one could concentrate on the centrally important functions and basic capabilities that measure poverty, one of which is the capability of a household to escape avoidable morbidity. 
Table 1. Dimensions, indicators, cutoffs and weights of the MPI

\begin{tabular}{|c|c|c|c|}
\hline Dimension & Indicator & Deprived if... & $\begin{array}{l}\text { Nested } \\
\text { weighting }\end{array}$ \\
\hline \multirow[t]{2}{*}{ Health } & Mortality & $\begin{array}{l}\text { Any child has died in the household in the past five years } \\
\text { prior to the survey }\end{array}$ & $16.7 \%$ \\
\hline & Morbidity & $\begin{array}{l}\text { Any adult household member has experienced illness in } \\
\text { the previous four weeks prior to the survey }\end{array}$ & $16.7 \%$ \\
\hline \multirow[t]{2}{*}{ Education } & $\begin{array}{l}\text { Years of } \\
\text { schooling }\end{array}$ & $\begin{array}{l}\text { No household member has completed any level of formal } \\
\text { schooling. }\end{array}$ & $16.7 \%$ \\
\hline & $\begin{array}{l}\text { Child } \\
\text { Enrollment }\end{array}$ & Any school-aged child* is not attending school. & $16.7 \%$ \\
\hline \multirow[t]{3}{*}{$\begin{array}{l}\text { Standard of } \\
\text { Living }\end{array}$} & Water & $\begin{array}{l}\text { The household does not have access to clean drinking } \\
\text { water. (If a household uses pond/dam, stream/river, } \\
\text { spring, or well the household is deprived). }\end{array}$ & $11.1 \%$ \\
\hline & Housing & The household has mud, wood, thatch (sar) roof. & $11.1 \%$ \\
\hline & Assets & $\begin{array}{l}\text { The household does not own more than one of: radio, } \\
\text { bed/table, kerosene lamp, kitchen utensils, jewelry, or ox } \\
\text { cart/bicycle, or do not own all farm tools (hoe, plough, } \\
\text { sickle or shovel/spade). }\end{array}$ & $11.1 \%$ \\
\hline
\end{tabular}

* In Ethiopia, the compulsory school age for children is 6-14 years (FDRE, 2009).

Years of schooling and child school enrollment are used as indicators to assess whether a household is deprived in the education dimension. A household is considered deprived in years of schooling if no member of the household has any level of formal schooling. Alkire and Santos (2010) use five years of schooling as the threshold to determine deprivation for the years of schooling indicator. We use formal schooling of any level because of the context of rural Ethiopia where about 35 percent of household members have not completed any schooling. The years of schooling indicator refers to all members of the household, thus giving the overall status of the household under review. In contrast, child school enrollment focuses on school-aged children in the household. A household is deprived in child enrollment if any one school-aged child is not enrolled in school, which shows household's ability to build future stock of education.

It is apparent that household size may influence whether a household is deprived in health and education dimensions. Large households are more likely to be deprived in child mortality, child enrollment and years of schooling by the mere fact that there are more individuals in the household reporting these deprivations. This suggests that there could be selection into the likelihood of being deprived in the first place due to household size. As Alkire and Santos (2010) state, this may be less of a problem in practice than in theory, particularly for health deprivation as data for all household members are rarely available. To 
explore such potential biases, we test the correlations of deprivation in these indicators and household size in section 4. For practical reasons, and following Alkire and Santos, if a household does not have a child, it is considered not deprived in health and education dimensions.

For the living standard dimension, we use access to water, quality of housing and assets as indicators. Access to water is based on the WHO/UNICEF definition of clean and safe water for the Millennium Development Goals. Following this definition, a household is taken as deprived in access to safe water if it uses pond, dam, stream, river, spring, or unprotected well. In contrast, if a household uses piped water both in the house and outside the house, borehole, or rainwater; then the household is considered not deprived in access to clean water. For deprivation in housing, we use the type of roof of the house as an indicator. If the roof is made from mud, wood, or thatch, then the household is taken as deprived. If the roof is made from galvanized iron, stone/brick, or concrete/cement, then the household is not taken as deprived in housing. The asset indicator is composed of major acquisitions needed by a typical household in rural Ethiopia (Table 1). The choice of the asset items is justified from the participatory poverty assessment report (2005) of Ethiopia. In particular, farm tools are essential component of rural livelihoods in the asset indicator. If a household owns all types of farm tools or two of the listed acquisitions, then a household is considered as not deprived in assets, otherwise it is considered as deprived in assets.

We use two different approaches concerning the weights attached to indicators in aggregating into a poverty index. The first approach attaches equal weights to all indicators in order to avoid any potential subjective bias, while the second approach uses nested weighting following Alkire and Santos (2010). In the nested weighting approach, equal weights are assigned to all three dimensions, and indicators within each dimension are given equal weights (last column of Table 1 for nested weighting).

\section{Descriptive results}

\subsection{Trends in deprivation of MPI indicators}

This section explores trends in deprivation of each of the MPI indicators. Deprivation in child mortality is found to decline consistently across the years while deprivation in morbidity has increased (see figure 1). Deprivation in education, captured by both years of 
schooling and child enrollment, is consistently declining over the years. We find that deprivation in years of schooling drops from about 43 percent in 1994 to about 10 percent in 2009. Deprivation in child enrollment declines from 63 percent in 1994 to 31 percent in 2009.

Similar to health and education dimension, deprivation in living standard shows a declining trend. Deprivation in assets declines sharply from 42 percent in 1994 to 4 percent in 2009. Deprivation in drinking water also declines from 81 percent in 1994 to 67 percent in 2009. The percentage of households deprived in quality of housing declines from 84 percent in 1994 to about 68 percent in 2009.

Overall, we find a consistent trend in almost all deprivation indicators, that deprivation has declined for these households in the period under review. A valid concern here is a decline in deprivation especially of child related indicators such as child mortality, child enrollment and years of schooling could be because of life cycle effects in that the household might not have an 'eligible' child to report these deprivations.

Figure 1. Percentage of households deprived in MPI indicators (1994-2009)

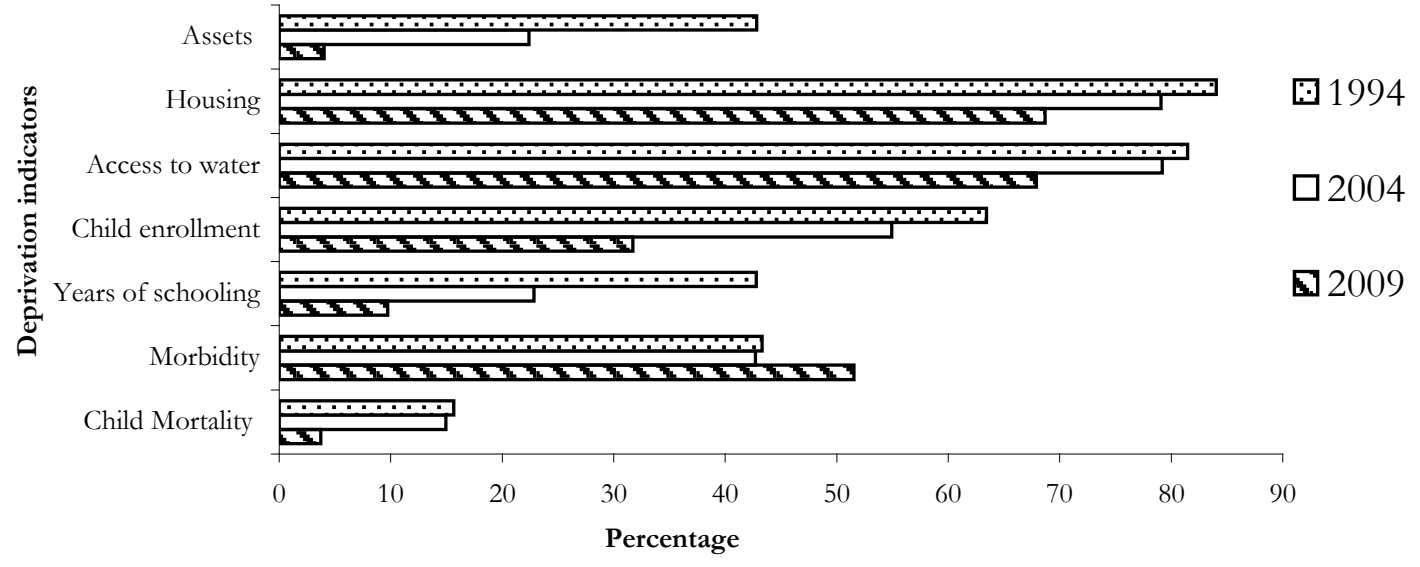

To further assess this concern and take into account the potential biases of deprivation indicators in relation to household size, as stated in section 3.2, we test for the mean difference of household size for each household size-related indicator. As shown in Table 2, we find no bias in child mortality because the mean value of household size for households deprived in child mortality is not significantly different from those households not deprived 
in child mortality. We also find no such bias in school year, in fact large households are less likely to be deprived in years of schooling as compared to small households and the mean difference is found to be statistically significant. This is, perhaps, because larger households have enough members for farm work, they can afford to send some other members to schools which explain the lower deprivation of larger households. The child enrollment indicator could potentially have such a bias as deprivation in child enrollment seems to follow household size in that large households are more likely to be deprived in child enrollment ${ }^{8}$. Hence, this indicator shall be interpreted with caution vis-à-vis the above bias. However, this possible bias in the MPI is balanced by the other indicators that are not related to life-cycle effect namely morbidity, assets, housing and access to water.

Table 2. Test for correlation of MPI indicators with Household size

\begin{tabular}{|c|c|c|c|c|c|c|c|}
\hline & \multicolumn{6}{|c|}{ Household size (mean) } \\
\hline & & 1994 & t-test & 2004 & t-test & 2009 & t-test \\
\hline \multirow{2}{*}{$\begin{array}{l}\text { Child } \\
\text { mortality }\end{array}$} & Deprived & 6.85 & \multirow{2}{*}{0.045} & 4.93 & \multirow{2}{*}{0.225} & 6.15 & \multirow{2}{*}{0.949} \\
\hline & Not deprived & 6.34 & & 5.17 & & 6.17 & \\
\hline Years of & Deprived & 5.39 & \multirow{2}{*}{0.000} & 3.70 & \multirow{2}{*}{0.000} & 4.91 & \multirow{2}{*}{0.000} \\
\hline schooling & Not deprived & 7.19 & & 5.57 & & 6.31 & \\
\hline Child & Deprived & 7.39 & \multirow{2}{*}{0.000} & 5.45 & \multirow{2}{*}{0.000} & 7.20 & \multirow{2}{*}{0.000} \\
\hline enrollment & Not deprived & 4.74 & & 4.64 & & 5.70 & \\
\hline
\end{tabular}

Looking at the distribution of deprivation counts over time (see figure 2 and Appendix 1), we find a decline in the peak number of deprivations. In 1994, 55 percent of households were deprived in 3 or 4 indicators. In 2004, 54 percent of households were deprived in 2 or 3 indicators and in 2009; about 51 percent of the households were deprived in 1 or 2 indicators. This shows that over the 15 years, the number of indicators for which households were deprived has decreased, indicating an improvement in welfare in terms of number of deprivations.

\footnotetext{
${ }^{8}$ Similar results are reported in a cross-country analysis of Alkire and Santos (2010).
} 
Figure 2. Distribution of deprivation counts in ERHS samples in rural Ethiopia

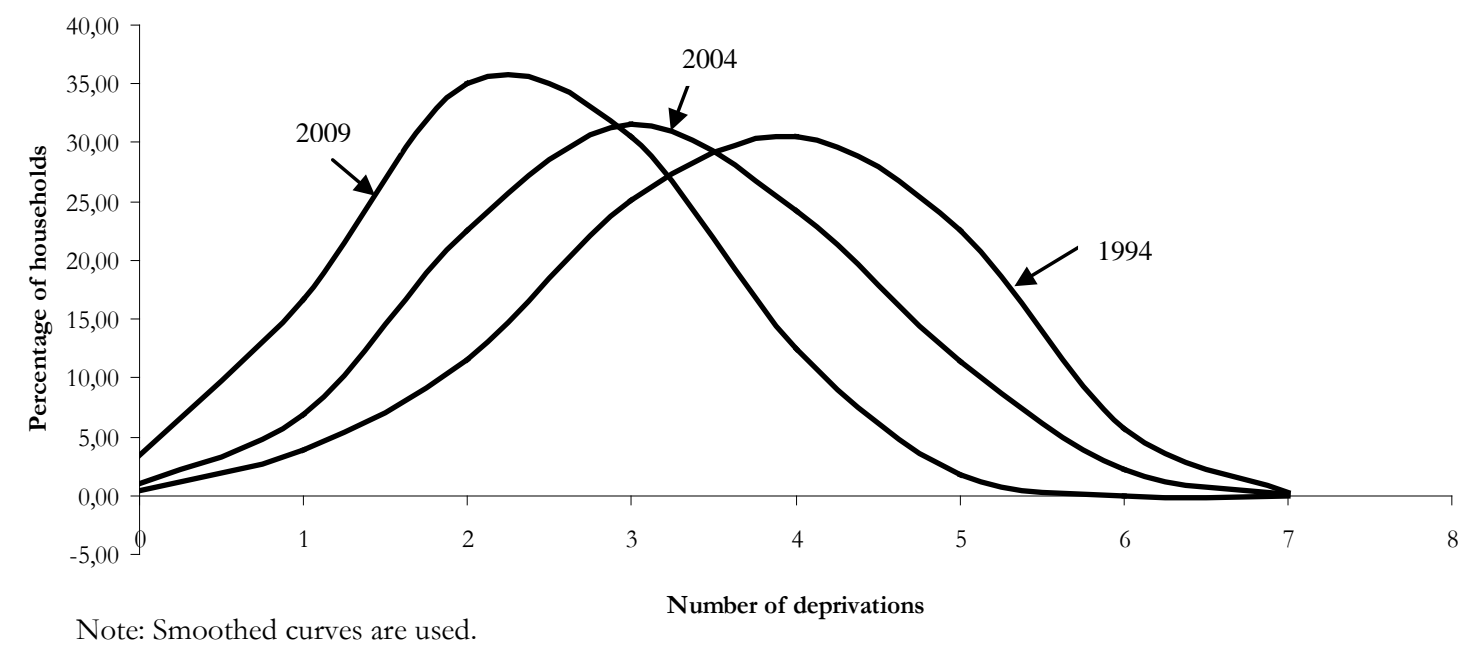

Before aggregating and comparing the trend in consumption poverty with that of multidimensional poverty, it is worth assessing the joint distribution of the various poverty indicators used in multidimensional poverty. The Pearson chi-squared is used to assess the dependency between the MPI indicators (Appendix 2). The result shows that indicators within dimensions are significantly dependent on each other. This is depicted by the significance probability between assets and housing deprivations in all three rounds and between drinking water and housing deprivations in two of the three rounds. The same is true for the education dimension where child enrollment and school year are found to be significantly dependent in two of the three rounds. This confirms that the categorization of the multidimensional indicators and the indicators within the dimensions are well-placed.

\subsection{Aggregation}

To aggregate poverty and calculate the adjusted head count ratio, we use both equal weights and nested weights, and then present results using different cut-off points $(k=2,3,4,5)$. For instance, the cut-off point $\mathrm{k}=2$ in equal weights indicates the proportion of households deprived in two or more indicators. The cut-off point $k=2$ in nested weights indicates the proportion of households deprived in number of indicators whose weighted sum equals two or more. We describe results for equal weights and nested weights in Table 3. 
For equal weights, multidimensional poverty declines over time, irrespective of the cut-off used. Using $\mathrm{k}=3$, for instance, about 49 percent of households were multidimensionally poor in 1994, while this declines to 37 percent in 2004 and to 21 percent in 2009 (Table 3 and Appendix 3). For nested weights, the result shows a similar trend with the results in equal weights. Adjusted head count ratio shows a declining trend over time in all cut-offs considered. For instance, using $\mathrm{k}=3$, the adjusted headcount ratio shows that 49 percent of households were multidimensional poor in 1994, which declined to 37 percent in 2004 and to 22 percent in 2009 . We detect not much difference in multidimensional poverty trend whether we use equal weights or nested weights. Hence, for the sake of ease of presentation, we use nested weights and $\mathrm{k}=3$ for the rest of the discussions in the paper. An important note here is that while the head count ratio $(H)$ and adjusted head count ratio $\left(M_{0}\right)$ show a declining trend, the poverty intensity (A) does not change much over time. This is especially true as $\mathrm{k}$ increases.

Table 3. Multidimensional poverty index: with equal weights and nested weights

\begin{tabular}{llcccc}
\hline Aggregate cut-off point (k) & & $\mathbf{k}=\mathbf{2}$ & $\mathbf{k}=\mathbf{3}$ & $\mathbf{k = 4}$ & $\mathbf{k = 5}$ \\
\hline Aggregation with equal weights & & & & & \\
\hline Head count ratio $(\mathrm{H})$ & 1994 & 0.956 & 0.842 & 0.591 & 0.286 \\
& 2004 & 0.920 & 0.694 & 0.379 & 0.137 \\
& 2009 & 0.798 & 0.448 & 0.142 & 0.018 \\
Average poverty or poverty Intensity & 1994 & 0.551 & 0.588 & 0.655 & 0.745 \\
(A) & 2004 & 0.477 & 0.540 & 0.633 & 0.741 \\
& 2009 & 0.394 & 0.479 & 0.589 & 0.714 \\
Adjusted headcount Ratio- Ratio of & 1994 & 0.528 & $\mathbf{0 . 4 9 5}$ & 0.387 & 0.213 \\
deprivations experienced by all poor & 2004 & 0.439 & $\mathbf{0 . 3 7 5}$ & 0.240 & 0.102 \\
households $\left(\mathrm{M}_{0}=\mathrm{AH}\right)$ & 2009 & 0.315 & $\mathbf{0 . 2 1 5}$ & 0.084 & 0.013 \\
\hline Aggregation with nested weights & & & & & \\
\hline Head count ratio $(\mathrm{H})$ & 1994 & 0.956 & 0.853 & 0.654 & 0.600 \\
& 2004 & 0.920 & 0.707 & 0.443 & 0.379 \\
& 2009 & 0.798 & 0.474 & 0.225 & 0.145 \\
Average poverty or poverty Intensity & 1994 & 0.551 & 0.584 & 0.634 & 0.652 \\
(A) & 2004 & 0.477 & 0.535 & 0.603 & 0.633 \\
& 2009 & 0.394 & 0.469 & 0.530 & 0.586 \\
Adjusted headcount Ratio- Ratio of & 1994 & 0.528 & $\mathbf{0 . 4 9 8}$ & 0.414 & 0.391 \\
deprivations experienced by all poor & 2004 & 0.439 & $\mathbf{0 . 3 7 9}$ & 0.267 & 0.240 \\
households $\left(\mathrm{M}_{0}=\mathrm{AH}\right)$ & 2009 & 0.315 & $\mathbf{0 . 2 2 2}$ & 0.119 & 0.085 \\
\hline
\end{tabular}




\subsection{Comparison of trends in consumption poverty and multidimensional poverty}

Trends in consumption poverty show that the percentage of households in poverty declined from 48 percent in 1994 to 37 percent in 2004, but it increased to a much higher level, 53 percent, in 2009 (Table 4). This rise in poverty from 2004 to 2009 could be due to factors including survey timing, increased food prices and drought shocks (Dercon et al., 2011). Dercon et al. state that several villages in Tigray and SNNPR experienced localized drought that caused considerable income losses. Moreover, the 2009 survey was conducted in the aftermath of rapid rise in food prices in 2008 and it was fielded approximately six months after the 2008 harvest. Given that many households in the ERHS villages are net food purchasers, the survey may have occurred just at the point where food stocks had run out and households were entering the market, where prices had already increased (Dercon et al., 2011). The overall effect of these factors is that households might have opted to reduce quantities consumed at the time of survey, which explains the radical decline in aggregate consumption expenditure in 2009.

Table 4. Consumption and multidimensional poverty indices (1994-2009)

\begin{tabular}{lccc}
\hline & $\mathbf{1 9 9 4}$ & $\mathbf{2 0 0 4}$ & $\mathbf{2 0 0 9}$ \\
\hline $\begin{array}{l}\text { Real consumption per capita per month } \\
\text { (average) using 1994 prices (in US\$) }\end{array}$ & 12.94 & 9.53 & 4.37 \\
$\begin{array}{l}\text { Consumption poor (\% of hhs) } \\
\text { Multidimensional head count ratio (\% of hhs }\end{array}$ & 48.75 & 37.74 & 53.93 \\
using nested weighting and k=3) & & 70.79 & 47.41 \\
\hline Sample size with complete information for all three rounds: 1044 & & \\
\hline
\end{tabular}

*Using poverty line $=$ US $\$ 9.2$

Comparing trends in head count ratio in multidimensional poverty (using nested weighting and $\mathrm{k}=3$ ), with the head count ratio in consumption poverty, we find similar trends for the first two years, but in the last round multidimensional poverty keeps on declining while consumption poverty increases (Table 4). In addition to the explanation above, the different trend in MPI and consumption poverty could also be linked to the fact that most of the MPI indicators are service provisions such as health, education and access to safe drinking water which the government has improved provisions via efforts to achieve the 2015 Millennium Development Goals (MDGs). This, perhaps, could explain the continuing smooth decline in multidimensional poverty through out the years under review (1994-2009). Comparing the trend in consumption poverty with the official poverty figures of the Ministry of Finance 
and Economic Development (MoFED) report (2012), poverty in rural Ethiopia has declined consistently over the years (Appendix 4). The MPI poverty trend is more consistently comparable to the trend of official poverty index than the consumption poverty result. But as explained earlier, the ERHS sample is not nationally representative and only covers rural non-pastoral areas, which might explain the disparity.

An interesting question, when comparing the two poverty measures, is whether the same households are identified as poor or non-poor by the consumption poverty and by the multidimensional poverty indices. We find that poverty/non-poverty status match between the two measures ranges between 48-57 percent of the sample households (Table 5). This shows that the two indices are comparable, for about $50 \% \mathrm{f}$ the sample, in terms of assigning similar status to a randomly drawn household from the sample. In addition, we find that a large portion of households that are MPI poor are not consumption poor. However, this percentage of households is declining over the years (from $40.9 \%$ to $18 \%$ ). In contrast, we observe an increase in the share of households that are MPI non-poor but consumption poor (from $4.31 \%$ to $24.52 \%$ ). Again, this could be explained by the inclusion of hiking prices in consumption aggregation.

Table 5. Comparing consumption and multidimensional poverty, percentage of households

\begin{tabular}{|c|c|c|c|c|c|c|c|}
\hline & & \multicolumn{6}{|c|}{ Consumption poverty } \\
\hline & & \multicolumn{2}{|r|}{1994} & \multicolumn{2}{|c|}{2004} & \multicolumn{2}{|r|}{2009} \\
\hline & & Poor & Non-poor & Poor & Non-poor & Poor & Non-poor \\
\hline \multirow{2}{*}{ MPI } & Poor & 44.44 & 40.90 & 28.35 & 42.43 & 29.41 & 18.01 \\
\hline & Non-poor & 4.31 & 10.34 & 9.39 & 19.83 & 24.52 & 28.07 \\
\hline \multicolumn{2}{|c|}{ Poverty status match* } & & 54.78 & & 48.18 & & 57.48 \\
\hline
\end{tabular}

* Status match is the percentage of households with similar poverty status in both measures.

To disentangle this further, we disaggregate households by consumption quintiles and assess their multidimensional poverty status. As we compare the poorest to the richest in terms of consumption poverty, the percentage of households that are multidimensionally poor decreases (Table 6). An interesting finding is that within the richest $20 \%$ of the sample population considered rich by the consumption measure, we find a significant number of households that are poor in MPI (figure ranging between 74 to 34 percent over the years). One explanation for this may be due to measurement error. However, as the difference is quite big, clearly part of the gap is attributable to an obvious difference between what the two poverty measures depict. 
Table 6. Consumption quintiles and MPI (1994, 2004 and 2009)

\begin{tabular}{llcl}
\hline & \multicolumn{4}{l}{ MPI poor (\% of households) } \\
\hline Consumption quintile & $\mathbf{1 9 9 4}$ & $\mathbf{2 0 0 4}$ & $\mathbf{2 0 0 9}$ \\
\hline 1 (poorest) & 96.17 & 76.56 & 61.24 \\
2 & 88.04 & 75.12 & 51.20 \\
3 & 86.60 & 70.81 & 51.67 \\
4 & 81.34 & 70.33 & 38.76 \\
5 (Richest) & 74.52 & 61.06 & 34.13 \\
\hline
\end{tabular}

Comparing real consumption per capita expenditure by each of the deprivation indicators we find that deprived households have lower average consumption expenditure when compared to non-deprived ones in almost all of the indicators (Table 7). The mean difference in consumption expenditure between deprived and non-deprived households is significant for child enrollment and assets (in all rounds), morbidity (in two rounds), drinking water and housing (in two rounds), and years of schooling (in one round). The mean difference in consumption expenditure for deprivation in child mortality does not show a significant difference in any of the rounds even though the mean value for deprived households is consistently lower than for non-deprived ones. In aggregate terms, households deprived in multidimensional indicators have consistently lower consumption expenditure with significantly different mean values in all rounds, which reinforce our finding about the overlap between consumption and multidimensional poverty indices.

Table 7. Real consumption expenditure by multidimensional poverty indicators

\begin{tabular}{|c|c|c|c|c|}
\hline & & \multicolumn{3}{|c|}{$\begin{array}{l}\text { Real consumption per capita expenditure per month } \\
\text { (average in US\$) }\end{array}$} \\
\hline & & 1994 & 2004 & 2009 \\
\hline \multirow[t]{2}{*}{ Child mortality } & Not deprived & 13.06 & 9.62 & 4.38 \\
\hline & Deprived & 12.31 & 9.01 & 3.89 \\
\hline \multirow[t]{2}{*}{ Morbidity } & Not deprived & 13.50 & 9.78 & 4.65 \\
\hline & Deprived & $12.20^{*}$ & 9.19 & $4.09^{* * *}$ \\
\hline \multirow{2}{*}{$\begin{array}{l}\text { Child } \\
\text { enrollment }\end{array}$} & Not deprived & 16.82 & 10.12 & 4.68 \\
\hline & Deprived & $10.70^{* * *}$ & $9.01^{* *}$ & $3.67^{* * *}$ \\
\hline \multirow{2}{*}{$\begin{array}{l}\text { Years of } \\
\text { schooling }\end{array}$} & Not deprived & 13.21 & 9.69 & 4.42 \\
\hline & Deprived & 12.57 & 8.97 & $3.78^{* *}$ \\
\hline \multirow[t]{2}{*}{ Asset } & Not deprived & 14.27 & 10.25 & 4.41 \\
\hline & Deprived & $11.15^{* * *}$ & $7.03^{* * *}$ & $3.10^{* * *}$ \\
\hline \multirow[t]{2}{*}{ Drinking water } & Not deprived & 16.44 & 8.37 & 4.41 \\
\hline & Deprived & $12.14^{* * *}$ & $9.83^{* *}$ & 4.34 \\
\hline \multirow[t]{2}{*}{ Housing } & Not deprived & 16.46 & 10.30 & 5.34 \\
\hline & Deprived & $12.27^{* * *}$ & 9.32 & $3.92^{* * *}$ \\
\hline \multirow{2}{*}{$\begin{array}{l}\text { Multidimension } \\
\text { al Indicators }\end{array}$} & Not deprived & 18.98 & 10.47 & 4.96 \\
\hline & Deprived & $11.90^{* * *}$ & $9.14^{* * *}$ & $3.70^{* * *}$ \\
\hline Sample size & 1044 & & & \\
\hline
\end{tabular}




\subsection{Poverty dynamics}

We describe poverty dynamics using consumption and multidimensional poverty first and then using each individual MPI indicator. In line with previous studies, we find that poverty is mainly transient in rural Ethiopia when using both consumption and multidimensional indices. Using consumption poverty index, about 63 percent of households are found to be poor in either one or two of the rounds (Table 8). This is consistent with other findings such as Dercon and Krishnan (2000), who, using earlier rounds of the ERHS data set and consumption poverty, find relatively high transitions in and out of poverty (30.1 percent). When MPI is used as a measure of poverty, about 60 percent of households are found to be poor in either one or two of the rounds.

Table 8. Movement of households in and out of poverty

\begin{tabular}{|c|c|c|c|c|c|c|c|c|c|}
\hline & $\begin{array}{l}\text { Consumption } \\
\text { poverty }\end{array}$ & MPI & $\begin{array}{l}\text { Child } \\
\text { mortality }\end{array}$ & $\begin{array}{l}\text { Adult } \\
\text { morbidity }\end{array}$ & $\begin{array}{l}\text { Child } \\
\text { enrollment }\end{array}$ & $\begin{array}{l}\text { School } \\
\text { year }\end{array}$ & Assets & $\begin{array}{l}\text { Drinking } \\
\text { water }\end{array}$ & Housing \\
\hline $\begin{array}{l}\text { Never } \\
\text { poor }\end{array}$ & $\begin{array}{l}229 \\
(21.87 \%)\end{array}$ & $\begin{array}{l}48 \\
(4.60 \%)\end{array}$ & $\begin{array}{l}742 \\
(70.87 \%)\end{array}$ & $\begin{array}{l}201 \\
(19.25 \%)\end{array}$ & $\begin{array}{l}146 \\
(13.94 \%)\end{array}$ & $\begin{array}{l}474 \\
(45.27 \%)\end{array}$ & $\begin{array}{l}491 \\
(46.9 \%)\end{array}$ & $\begin{array}{l}21 \\
(2.01 \%)\end{array}$ & $\begin{array}{l}121 \\
(11.56 \%)\end{array}$ \\
\hline $\begin{array}{l}\text { Once } \\
\text { poor }\end{array}$ & $\begin{array}{l}324 \\
(30.95 \%)\end{array}$ & $\begin{array}{l}229 \\
(21.93 \%)\end{array}$ & $\begin{array}{l}254 \\
(24.26 \%)\end{array}$ & $\begin{array}{l}375 \\
(35.73 \%)\end{array}$ & $\begin{array}{l}385 \\
(36.77 \%)\end{array}$ & $\begin{array}{l}398 \\
(38.01 \%)\end{array}$ & $\begin{array}{l}409 \\
(39.06 \%)\end{array}$ & $\begin{array}{l}203 \\
(19.39 \%)\end{array}$ & $\begin{array}{l}95 \\
(9.07 \%)\end{array}$ \\
\hline $\begin{array}{l}\text { Twice } \\
\text { poor }\end{array}$ & $\begin{array}{l}334 \\
(31.90 \%)\end{array}$ & $\begin{array}{l}405 \\
(38.79 \%)\end{array}$ & $\begin{array}{l}47 \\
(4.49 \%)\end{array}$ & $\begin{array}{l}347 \\
(33.24 \%)\end{array}$ & $\begin{array}{l}366 \\
(34.96 \%)\end{array}$ & $\begin{array}{l}134 \\
(12.8 \%)\end{array}$ & $\begin{array}{l}126 \\
(12.03 \%)\end{array}$ & $\begin{array}{l}279 \\
(26.65 \%)\end{array}$ & $\begin{array}{l}161 \\
(15.38 \%)\end{array}$ \\
\hline $\begin{array}{l}\text { Three } \\
\text { times } \\
\text { (Always) } \\
\text { poor }\end{array}$ & $\begin{array}{l}160 \\
(15.28 \%)\end{array}$ & $\begin{array}{l}362 \\
(34.67 \%)\end{array}$ & $\begin{array}{l}4 \\
(0.38 \%)\end{array}$ & $\begin{array}{l}123 \\
(11.78 \%)\end{array}$ & $\begin{array}{l}150 \\
(14.33 \%)\end{array}$ & $\begin{array}{l}41 \\
(3.92 \%)\end{array}$ & $\begin{array}{l}21 \\
(2.01 \%)\end{array}$ & $\begin{array}{l}544 \\
(51.96 \%)\end{array}$ & $\begin{array}{l}670 \\
(63.99 \%)\end{array}$ \\
\hline $\begin{array}{l}\text { Transient } \\
\text { status* } \\
\text { Persistent }\end{array}$ & $63.00 \%$ & $60.72 \%$ & $28.75 \%$ & $68.97 \%$ & $71.73 \%$ & $50.81 \%$ & $51.09 \%$ & $46.04 \%$ & $24.45 \%$ \\
\hline status ${ }^{* *}$ & $37.10 \%$ & $39.27 \%$ & $71.25 \%$ & $31.03 \%$ & $28.27 \%$ & $49.19 \%$ & $48.91 \%$ & $53.97 \%$ & $75.55 \%$ \\
\hline Total & $\begin{array}{l}1,044 \\
(100 \%)\end{array}$ & $\begin{array}{l}1,044 \\
(100 \%)\end{array}$ & $\begin{array}{l}1,044 \\
(100 \%)\end{array}$ & $\begin{array}{l}1,044 \\
(100 \%)\end{array}$ & $\begin{array}{l}1,044 \\
(100 \%)\end{array}$ & $\begin{array}{l}1,044 \\
(100 \%)\end{array}$ & $\begin{array}{l}1,044 \\
(100 \%)\end{array}$ & $\begin{array}{l}1,044 \\
(100 \%)\end{array}$ & $\begin{array}{l}1,044 \\
(100 \%)\end{array}$ \\
\hline
\end{tabular}

* Transient status is the sum of percentage of households who were poor once or twice.

** Persistent status is the sum of percentage of households who were never poor or always poor.

Using each of the MPI indicators, we find mixed results about poverty dynamics. Half of the MPI indicators are found to depict transient nature and the other half indicates persistency. As shown in Table 8, indicators of education (both child enrollment and years of schooling), morbidity, and assets are found to be transient. This is expected because studies show that households tend to take children out of school or sell their assets when facing certain shocks in order to use these resources (time and financial) as coping mechanisms (Kochar, 1995; Jacoby and Skoufias, 1992). 
Child mortality and two of the living standard indicators (i.e. access to drinking water and housing) are found to be persistent in that most households never changed their status in the period under review. Regarding housing and access to drinking water most households were persistent in that they were deprived in all three rounds. This result is plausible as a household is less likely to change its quality of housing and access to water as compared to its assets and education when faced with certain shocks. This implies that quality of housing and access to water are indicators of structural poverty (non-poverty).

Overall, these findings imply that even though consumption poverty measure captures mobility of households in and out poverty over time, we find that other indicators such as education and assets (used in the MPI poverty measure) also depict the transient nature of poverty.

\subsection{Transition probabilities}

Transition probabilities show possible changes in poverty or deprivation status, namely a household that had been consumption poor in the previous survey could either remain poor or become non-poor in the following survey round. This same analogy works for the multidimensional poverty measure. Transitional probabilities depend on the total number of households in the sample and distributions of households in and out of poverty. As shown in Table 9, we find that of all the possible transitions (i.e. regardless of their initial status), the probability of a household becoming consumption poor in any one of the survey rounds is 45.9 percent while for multidimensional poverty, this figure increases to 59.1 percent.

Using consumption poverty measure, of those that started poor, 53 percent remained poor; while of those that started non-poor, 59 percent remained non-poor. For the MPI measure, the probabilities show that of those households that started as deprived, 64 percent remained deprived while of those that started non-deprived, 60 percent remained nondeprived (Table 9). This suggests that in both consumption and the MPI measure of poverty, substantial persistency in poverty/deprivation and non-poverty/non-deprivation is observed, while this persistency is relatively higher in the case of MPI when compared to consumption poverty. Our finding is consistent with Bigsten and Shimeles (2008) who find substantial 
persistency of poverty and non-poverty in consumption poverty of rural households in Ethiopia.

In terms of mobility, we find that the consumption poverty measure depicts relatively higher mobility in to and out of poverty when compared to the MPI. This is as expected since, by construction, the MPI is composed of long-term indicators. This finding is similar to that of Bigsten and Shimeles (2008), who find that mobility in to and out of poverty is more extensive in rural areas. Tsehay and Bauer (2012) also confirm, using consumption as a measure of poverty, that households exhibit higher mobility in rural Ethiopia.

Table 9. Transition probabilities of consumption poverty, MPI, and MPI indicators

\begin{tabular}{|c|c|c|c|}
\hline & & Not deprived & Deprived \\
\hline \multirow[t]{8}{*}{ Health } & 1. Child mortality & & \\
\hline & Not deprived & 91.77 & 8.23 \\
\hline & Deprived & 84.42 & 15.58 \\
\hline & Total & 90.64 & 9.38 \\
\hline & 2. Morbidity & & \\
\hline & Not deprived & 56.47 & 43.53 \\
\hline & Deprived & 48.11 & 51.89 \\
\hline & Total & 52.87 & 47.13 \\
\hline \multirow[t]{8}{*}{ Education } & 3. Child enrollment & & \\
\hline & Not deprived & 67.25 & 32.75 \\
\hline & Deprived & 50.00 & 50.00 \\
\hline & Total & 57.12 & 42.88 \\
\hline & 4. Years of schooling & & \\
\hline & Not deprived & 90.12 & 9.88 \\
\hline & Deprived & 70.60 & 29.40 \\
\hline & Total & 83.72 & 16.28 \\
\hline \multirow[t]{12}{*}{ Living Standard } & 5. Assets & & \\
\hline & Not deprived & 91.57 & 8.43 \\
\hline & Deprived & 76.83 & 23.17 \\
\hline & Total & 86.77 & 13.23 \\
\hline & 6. Access to drinking & vater & \\
\hline & Not deprived & 41.99 & 58.01 \\
\hline & Deprived & 22.65 & 77.35 \\
\hline & Total & 26.46 & 73.54 \\
\hline & 7. Housing quality & & \\
\hline & Not deprived & 85.49 & 14.51 \\
\hline & Deprived & 12.70 & 87.30 \\
\hline & Total & 26.12 & 73.88 \\
\hline \multicolumn{4}{|c|}{ Aggregate poverty index } \\
\hline \multirow[t]{4}{*}{ MPI } & Not deprived & 59.61 & 40.39 \\
\hline & Deprived & 35.64 & 64.36 \\
\hline & Total & 40.90 & 59.10 \\
\hline & & Non-poor & Poor \\
\hline \multirow{3}{*}{$\begin{array}{l}\text { Consumption } \\
\text { poverty }\end{array}$} & Not poor & 59.85 & 40.15 \\
\hline & Poor & 46.47 & 53.53 \\
\hline & Total & 54.06 & 45.94 \\
\hline
\end{tabular}


Looking at each of the MPI indicators, the transition probability for child mortality shows a high probability for households to keep their status of non-deprivation or to change into the status of non-deprivation if they were deprived in the initial condition (Table 9). Years of schooling and asset indicators exhibit a similar trend. The indicator of child enrollment has also a similar trend with an equal probability of a household to stay deprived or move into non-deprivation if initially deprived. This persistence in non-deprivation and becoming nondeprived if they were deprived in the initial status shows that there seems to be improvement in these welfare dimensions namely child mortality, child enrollment, years of schooling and assets.

In contrast, indicators of access to safe drinking water, quality of housing, and to some extent morbidity show different trends. Access to drinking water exhibits persistency in deprivation and higher probability of changing into deprivation if a household was not initially deprived. Quality of housing and morbidity show persistency in both deprivation and non-deprivation. This suggests that not much welfare improvement is observed for households in terms of access to drinking water and quality of housing both being indicators for living standard dimension of the MPI.

A logical follow-up question is then, what drives such transition of households in consumption and multidimensional poverty? Studies (Dercon and Krishnan, 2000; Bigsten and Shimeles, 2008) suggest that changes in household welfare is affected by idiosyncratic and covariate shocks in addition to the socio-economic and demographic characteristics of households. Short-lived shocks, such as rainfall and household-specific crop failure, could result in temporary mobility of households into poverty while shocks that have lasting impacts result in households becoming permanently poor. In the following sub-section we analyze the determinants of poverty dynamics with specific focus on rainfall/drought shocks. First a brief description of the shock variables used is in order.

\subsection{Shocks}

The ERHS survey asks households whether they faced specific shocks during the past 10 years for the 2004 survey round and over the past 5 years for the 2009 survey round. Since information on shocks is available in the 2004 and 2009 survey only, the econometrics 
analysis in section 5 uses these two rounds of surveys. We focus on the main shocks reported by the majority of households, such as drought, death of household member, illness of household member, pests affecting households' crop on field or on storage, pests affecting households' livestock, and shocks related to outputs (including inability to sell outputs or decrease in agricultural output prices). These shocks are found to be reported by majority of respondents in the ERHS survey. ${ }^{\text {? }}$

Drought shock is the most important shock, affecting more than 50 percent of the sample households. For instance Dercon et al. (2011) state that several villages in Tigray and SNNPR experienced localized drought that caused considerable income losses in between 2004 and 2009. The second most common shock reported by households is a health shock, such as death and illness of a household member (Table 10). The percentages of households reporting shocks related to pests affecting crops on field or on storage outnumber those that report shocks on pests affecting household livestock. Output shocks are found to affect about 26 percent of households in 2004. Looking at the change over time of vulnerability to shocks, we find that the percentage of households affected by shocks declines consistently for all types of shocks.

Table 10. Percentage of households who faced shocks

\begin{tabular}{llll}
\hline Shocks & $\mathbf{2 0 0 4}$ & $\mathbf{2 0 0 9}$ & $\begin{array}{l}\text { Pearson Chi2 } \\
\text { significance level }\end{array}$ \\
\hline Drought & $58.73 \%$ & $41.99 \%$ & 0.000 \\
Death of household member & $46.80 \%$ & $18.75 \%$ & 0.334 \\
Illness of household member & $34.37 \%$ & $23.04 \%$ & 0.040 \\
Pests affecting households' crops & $28.44 \%$ & $25.40 \%$ & 0.000 \\
$\begin{array}{l}\text { On field or on storage } \\
\text { Pests affecting households' }\end{array}$ & $17.35 \%$ & $14.42 \%$ & 0.004 \\
livestock & & & \\
Shocks related to output & $26.91 \%$ & $3.45 \%$ & 0.267 \\
\hline
\end{tabular}

\section{Econometric results}

\subsection{Empirical strategy}

To assess the determinants of poverty dynamics, we employ panel data models using 2004 and 2009 survey rounds. We do this for both consumption and multidimensional poverty,

\footnotetext{
${ }^{9}$ For a detailed report on shocks and household vulnerability in Ethiopia using similar data set, see Dercon et
} al. (2005). 
comparing the results. The major issue in panel data analysis is controlling for time-invariant unobserved heterogeneity in the observations. For this, standard econometric methodology suggests the use of efficient panel data estimators, such as fixed effect estimators (Wooldridge, 2002), that accounts for inter-temporal and individual differences.

Adopting this methodology, we specify the following equation:

$$
Y_{i t}=\beta X_{i t}+\gamma Z_{i t}+a_{i}+u_{i t}
$$

Where $Y_{i t}$ is the dependent variable observed for household $i$ at time $t, X_{i t}$ is a vector of explanatory variables for household $i$ at time $t, Z_{i t}$ is a vector of shocks faced by household $i$ at time $t, \beta$ and $\gamma$ are vector of coefficients; $a_{i}$ denotes unobserved household specific effects assumed to be fixed over time and vary across households; and $U_{i t}$ is the error term.

The dependent variable is a dummy that takes a value of 1 when a household is poor in consumption poverty or deprived in multidimensional poverty. We use fixed effects logit model that enables us to control for unobserved time-invariant characteristics of households. Fixed effects logit estimators use only within-household differences, essentially discarding any information about differences between households. This means that if there is no variation within a household's poverty status between 2004 and 2009 survey rounds, then that household is dropped from the analysis. Hence, the analysis is only conducted on households that switched from one status of poverty or deprivation to another, which explains the sample size change when the dependent variable changes.

In line with standard panel studies, we control for demographic and socio-economic characteristics of households, such as household size, education of household, and membership in informal saving and credit association among others.

\subsection{Econometric results}

Our finding shows that number of literate household members decreases the likelihood of becoming consumption poor (Table 11). Larger household size is found to significantly increase the likelihood of a household to be consumption poor. Off-farm employment is found to have a different effect on consumption and multidimensional poverty in that it is 
found to decrease the likelihood of falling into consumption poverty, while it is found to increase multidimensional poverty, but only at marginally significant levels. We also find that households with access to loans and membership in an informal saving association (Equb) are less likely to be consumption and multidimensional poor.

Looking at the effect of shocks on the change in consumption poverty, we find that an exogenous shock, such as drought, has a significant effect on increasing consumption poverty. The result in column 1 shows that effect of drought shock is quite significant and positive. When controlling for other shocks that households face, we find that drought shock still has significant and positive effect on consumption poverty. The other shock that has significant positive effect is output shocks related to inability to sell outputs or decrease in agricultural output prices. However, we do not find similar effect of shocks on multidimensional poverty. For multidimensional poverty, the effect of experiencing drought is not significant as shown in column 5 and 6. This could be because multidimensional poverty is composed of long-term welfare indicators that do not seem to be affected by a short-term shock occurrence, as our empirical evidence shows. We, however, find that shocks, such as input price increase, have a positive and significant effect on multidimensional poverty.

We take the number of shocks experienced by a household over the previous 10 years for the 2004 survey, and over the past 5 years for the 2009 survey as explanatory variable. We find that the number of shocks that households simultaneously face have significant and positive effect on multidimensional poverty (column 7). The number of shocks that households face is also significant and positive when interacted with whether households faced an exogenous shock such as drought. However, we find that this is not the case for consumption poverty (see results in column 3 and 4).

Comparing determinants for changes in status of consumption poverty and multidimensional poverty, we find that household size has a significant and positive effect on consumption poverty while the level of significance declines for multidimensional poverty. While larger sized households have a tendency to change their status into consumption poverty, they do not change into multidimensional poverty. Our finding attests 
to emerging empirical evidence on multidimensional poverty and household size in that household size matters a lot less for multidimensional poverty than consumption poverty. ${ }^{10}$

\section{Table 11. Determinants of consumption and multidimensional poverty dynamics}

\begin{tabular}{|c|c|c|c|c|c|c|c|c|}
\hline & \multicolumn{4}{|c|}{$\begin{aligned} & \text { Dependent variable: Consumption poverty } \\
= & 1 \text { if household is consumption poor, } 0 \text { otherwise }\end{aligned}$} & \multicolumn{4}{|c|}{$\begin{array}{l}\text { Dependent variable: Multidimensional poverty } \\
=1 \text { if household is MPI poor, } 0 \text { otherwise }\end{array}$} \\
\hline & $(1)$ & $(2)$ & (3) & $(4)$ & $(5)$ & $(6)$ & $(7)$ & $(8)$ \\
\hline \multicolumn{9}{|c|}{ Socio-economic household characteristic } \\
\hline $\begin{array}{l}\text { Number of literate } \\
\text { household members }\end{array}$ & $\begin{array}{c}-0.101 \\
(0.0775)\end{array}$ & $\begin{array}{l}-0.0974 \\
(0.0824)\end{array}$ & $\begin{array}{l}-0.0825 \\
(0.0783)\end{array}$ & $\begin{array}{c}-0.118 \\
(0.0746)\end{array}$ & & & & \\
\hline Household size & $\begin{array}{c}0.292 * * * \\
(0.0670)\end{array}$ & $\begin{array}{l}0.283^{* * *} \\
(0.0689)\end{array}$ & $\begin{array}{c}0.289 * * * \\
(0.0670)\end{array}$ & $\begin{array}{c}0.276^{* * *} \\
(0.0655)\end{array}$ & $\begin{array}{c}0.0545 \\
(0.0587)\end{array}$ & $\begin{array}{c}0.0454 \\
(0.0613)\end{array}$ & $\begin{array}{c}0.0281 \\
(0.0611)\end{array}$ & $\begin{array}{c}0.0371 \\
(0.0600)\end{array}$ \\
\hline $\begin{array}{l}\text { household engages in } \\
\text { off farm employment }\end{array}$ & $\begin{array}{c}-0.348^{*} \\
(0.186)\end{array}$ & $\begin{array}{c}-0.374^{*} \\
(0.197)\end{array}$ & $\begin{array}{c}-0.352^{*} \\
(0.188)\end{array}$ & $\begin{array}{l}-0.282 \\
(0.180)\end{array}$ & $\begin{array}{c}0.437 * * \\
(0.208)\end{array}$ & $\begin{array}{c}0.333 \\
(0.216)\end{array}$ & $\begin{array}{l}0.371 * \\
(0.213)\end{array}$ & $\begin{array}{c}0.423^{* *} \\
(0.208)\end{array}$ \\
\hline $\begin{array}{l}\text { Household received } \\
\text { remittance }\end{array}$ & $\begin{array}{l}0.0569 \\
(0.178)\end{array}$ & $\begin{array}{l}0.0837 \\
(0.189)\end{array}$ & $\begin{array}{l}0.0394 \\
(0.179)\end{array}$ & $\begin{array}{c}0.190 \\
(0.173)\end{array}$ & $\begin{array}{l}0.394^{*} \\
(0.211)\end{array}$ & $\begin{array}{l}0.417 * \\
(0.221)\end{array}$ & $\begin{array}{c}0.427 * * \\
(0.215)\end{array}$ & $\begin{array}{c}0.315 \\
(0.206)\end{array}$ \\
\hline $\begin{array}{l}\text { Household has taken } \\
\text { loan }\end{array}$ & $\begin{array}{l}-0.0821 \\
(0.193)\end{array}$ & $\begin{array}{l}-0.118 \\
(0.201)\end{array}$ & $\begin{array}{c}-0.0550 \\
(0.193)\end{array}$ & $\begin{array}{c}-0.00527 \\
(0.188)\end{array}$ & $\begin{array}{l}-0.226 \\
(0.224)\end{array}$ & $\begin{array}{l}-0.110 \\
(0.235)\end{array}$ & $\begin{array}{l}-0.226 \\
(0.228)\end{array}$ & $\begin{array}{l}-0.222 \\
(0.224)\end{array}$ \\
\hline $\begin{array}{c}\text { Household is member } \\
\text { of ' } E q u b{ }^{+}\end{array}$ & $\begin{array}{l}-0.533^{*} \\
(0.299)\end{array}$ & $\begin{array}{l}-0.489 \\
(0.312)\end{array}$ & $\begin{array}{l}-0.506^{*} \\
(0.302)\end{array}$ & $\begin{array}{c}-0.615^{* *} \\
(0.296)\end{array}$ & $\begin{array}{l}-0.105 \\
(0.289)\end{array}$ & $\begin{array}{l}-0.371 \\
(0.307)\end{array}$ & $\begin{array}{l}-0.180 \\
(0.296)\end{array}$ & $\begin{array}{l}-0.0975 \\
(0.290)\end{array}$ \\
\hline \multicolumn{9}{|c|}{ Shock reporting by households } \\
\hline $\begin{array}{c}\text { Household experienced } \\
\text { drought }\end{array}$ & $\begin{array}{c}0.782^{* * *} \\
(0.230)\end{array}$ & $\begin{array}{c}0.999 * * * \\
(0.249)\end{array}$ & $\begin{array}{c}0.852^{* * *} \\
(0.234)\end{array}$ & & $\begin{array}{c}-0.0932 \\
(0.255)\end{array}$ & $\begin{array}{c}-0.0558 \\
(0.266)\end{array}$ & $\begin{array}{l}-0.131 \\
(0.258)\end{array}$ & \\
\hline $\begin{array}{l}\text { Number of shocks } \\
\text { simultaneously faced }\end{array}$ & & & $\begin{array}{c}-0.0797 * * \\
(0.0369)\end{array}$ & & & & $\begin{array}{c}0.129 * * * \\
(0.0415)\end{array}$ & \\
\hline $\begin{array}{l}\text { Drought incidence } * \\
\text { number of shocks faced }\end{array}$ & & & & $\begin{array}{l}-0.0149 \\
(0.0343)\end{array}$ & & & & $\begin{array}{l}0.0743 * \\
(0.0443)\end{array}$ \\
\hline $\begin{array}{c}\text { Household faced death } \\
\text { of hhs member }\end{array}$ & & $\begin{array}{l}0.0187 \\
(0.192)\end{array}$ & & & & & & \\
\hline $\begin{array}{c}\text { Household faced illness } \\
\text { of hhs member }\end{array}$ & & $\begin{array}{l}-0.170 \\
(0.200)\end{array}$ & & & & & & \\
\hline $\begin{array}{l}\text { Household faced pests } \\
\text { on crops }\end{array}$ & & $-0.516^{* *}$ & & & & -0.0241 & & \\
\hline Household faced pests & & $\begin{array}{c}(0.225) \\
-0.530 * *\end{array}$ & & & & $\begin{array}{c}(0.235) \\
0.460\end{array}$ & & \\
\hline that affected livestock & & $(0.261)$ & & & & $(0.291)$ & & \\
\hline Household faced input & & 0.0267 & & & & $0.590 * *$ & & \\
\hline price increase & & $(0.228)$ & & & & $(0.245)$ & & \\
\hline Household faced & & $0.633^{* *}$ & & & & 0.305 & & \\
\hline shocks related to output & & $(0.293)$ & & & & $(0.322)$ & & \\
\hline 2009 year dummy & $\begin{array}{c}0.723^{* * *} \\
(0.160)\end{array}$ & $\begin{array}{c}0.867 * * * \\
(0.195)\end{array}$ & $\begin{array}{c}0.676 * * * \\
(0.162)\end{array}$ & $\begin{array}{c}0.487 * * * \\
(0.146)\end{array}$ & $\begin{array}{c}-1.647 * * * \\
(0.178)\end{array}$ & $\begin{array}{c}-1.710^{* * *} \\
(0.206)\end{array}$ & $\begin{array}{c}-1.537 * * * \\
(0.181)\end{array}$ & $\begin{array}{c}-1.519 * * * \\
(0.177)\end{array}$ \\
\hline Observations & 772 & 732 & 772 & 772 & 754 & 734 & 754 & 754 \\
\hline
\end{tabular}

10 These empirical results were presented during the research workshop on "Dynamic Comparison between Multidimensional Poverty and Monetary Poverty," held in Oxford on 21-22 November 2012, available at: http://www.ophi.org.uk/participants-describe-key-findings-of-dynamic-comparison-workshop 
Another important comparison of determinants of changes in status of consumption and multidimensional poverty concerns shocks. Our result suggests that occurrence of drought increases the likelihood of households changing their status into consumption poverty and this effect is quite significant. However, we do not find such significant effects of any individual exogenous shock on multidimensional poverty. Rather, for multidimensional poverty, we find that the number of simultaneous shocks faced by households has a significant effect. This implies that for the multidimensional poverty measure, composed of long-term welfare indicators, it is the simultaneous shocks that have more significant effect as compared to one time/one event shock. This has clear implications for policy as discussed in the final section.

Table 12. Determinants of selected multidimensional poverty indicators

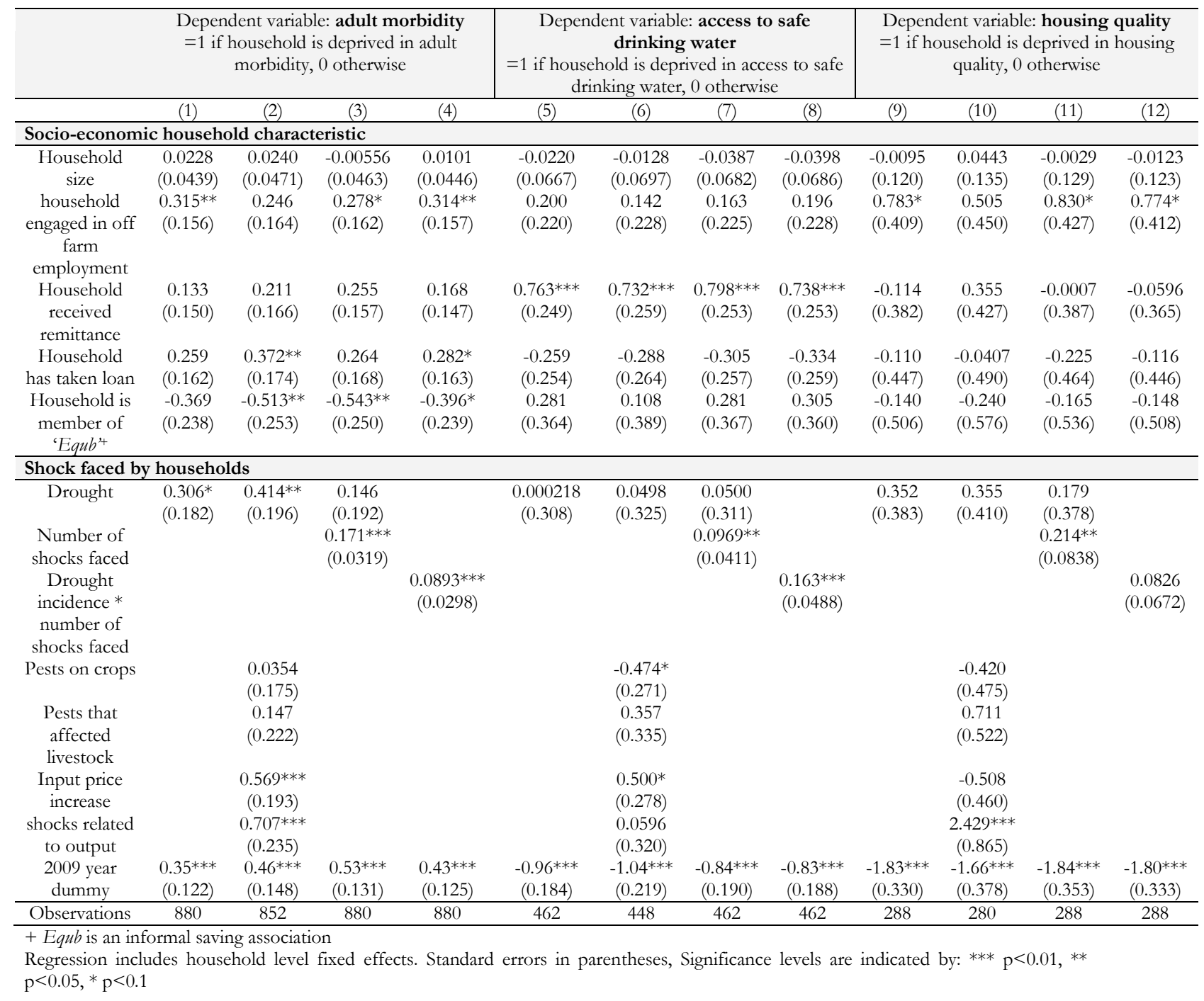


To explore which of the indicators of the MPI index are significantly responsive to simultaneous occurrence of shocks, we took three of the indicators depicting persistency in the MPI index namely, access to safe drinking water, housing quality and to some extent adult morbidity. Using fixed effects model, we find that results of these indicators are consistent with the general MPI index as shown in Table $12^{11}$.

The findings show that occurrence of many shocks simultaneously affects deprivations in morbidity, access to safe drinking water, and housing quality significantly. This implies that simultaneous shocks affect the structural character of welfare. In contrast, occurrence of drought shock is found to have a significant effect only on morbidity. We also find that deprivation in morbidity is significantly affected by shocks in input prices and shocks related to output. Furthermore, output shocks have significant effects on deprivations in housing quality. Overall, the findings confirm that indeed those indicators capturing persistency within the MPI index are significantly affected by occurrence of simultaneous shocks.

\section{Conclusion}

This paper analyses poverty dynamics and its determinants in rural Ethiopia using consumption expenditure and multidimensional poverty indices. For this, we use panel data from the Ethiopian Rural Household Survey collected in 1994, 2004, and 2009. The major contribution of our study to the poverty literature is that we construct the multidimensional poverty index using indicators that fit the context of rural Ethiopia and analyze poverty dynamics of the multidimensional nature and compare its trend to consumption poverty. In addition, we assess the determinants of poverty dynamics in relation to various shocks using both measures of poverty.

Exploring poverty measures using MPI and consumption poverty measure, results show that the two measures assign similar poverty status to 48-57 percent of households during the period under review. Moreover, we find that amongst the richest $20 \%$ of the sample by consumption poverty measure, some proportion of households is found to be MPI poor (figure ranging between 74 to 34 percent between 1994 and 2009). This implies that the gap

\footnotetext{
${ }^{11}$ We also run regressions for each of the other MPI indicators; however, we don't find significant results. For the sake of conciseness, these results are not presented here. They shall be made available upon request.
} 
between the two poverty measures in non-negligible. We also find that the trend in poverty is different (between 2004 and 2009) when using these two poverty measures, which could be partly explained by inclusion of high prices between 2004 and 2009 in the consumption poverty measure. The transient nature of poverty in rural Ethiopia is confirmed by both consumption and MPI measures of poverty. From the MPI indicators, poverty transition is depicted by assets, child enrollment and school year. Housing quality and access to safe drinking water show persistency in deprivation. This implies that intervention is needed regarding these welfare indicators in order to help households move out of chronic poverty.

What comes out of these findings is the need to use both consumption and multidimensional poverty indices as complements to understand the extent, diversity and dynamics of poverty over time. It also shows that disaggregating deprivations helps to bring out which indicators need to be focused on to address specific target groups, namely the chronically poor/deprived as compared to the transient poor. Indeed, having such complementary measures brings the picture into clear focus.

In order to link poverty dynamics to policy changes, we assessed the drivers of poverty dynamics using both measures. The result that smaller sized households with educated members have a lesser tendency to move into consumption poverty implies that family planning and actions towards promoting education are important to poverty reduction efforts. This finding is in line with the research, where household size matters more for consumption poverty than for multidimensional poverty. In addition, creating access to formal and informal credit is important for reducing both consumption and multidimensional poverty.

The result that drought shocks are found to affect consumption poverty while no such effect is found for multidimensional poverty implies that such short-term shocks are more reflected in transient poverty measures. However, the effect of simultaneous shocks is found to be reflected on multidimensional poverty measure reflecting long-term (structural) poverty. In particular, the persistency indicators of MPI such as housing quality and access to safe drinking water are found to be significantly affected by the number of simultaneous shocks. This calls for the need to design and prioritize policy interventions to households 
facing multiple shocks as this addresses structural poverty (long-term welfare). Policies promoting safety nets against specific types of shocks are more effective in addressing transient welfare indicators such as consumption poverty. Hence, understanding the nature of poverty and/or deprivations using both consumption and MPI is important to targeting specific deprivations via policy interventions. Our result vividly shows that it is important to take into account long-term welfare indicators, such as MPI, to complement with conventional poverty measures to understand poverty, its dynamics and drivers to come up with effective policy options. 


\section{Reference}

Alkire, S. and J. Foster (2011). Counting and multidimensional poverty measurement. Journal of public economics, 95(7-8):476-487.

Alkire, S. and J. Foster (2007). Counting and multidimensional poverty measurement. OPHI working paper series No. 07, Oxford Poverty and Human Development Initiative (OPHI), University of Oxford.

Alkire, S. and M. E. Santos (2010). Acute multidimensional poverty: A new index for developing countries. Human development research paper, 2010/2011. UNDP, USA.

Bane, M. J., and Ellwood, D. T. (1986). Slipping into and out of poverty: The dynamics of Spells. Journal of Human Resources, 21(1), 1-23.

Baulch, B. and J. Hoddinott (2000). Economic mobility and poverty dynamics in developing countries. Journal of Development Studies, 36(6), 1-24.

Bigsten, A., B. Kebede, A. Shimeles, and M. Taddesse (2003). Growth and poverty reduction in Ethiopia: evidence from household panel surveys. World Development, 3(1), 87-106.

Bigsten, A. and A. Shimeles (2008). Poverty transition and persistence in Ethiopia: 19942004. World Development, 36(9), 1559-1584.

Bourguignon, F. and S.R. Chakravarty (2003). The measurement of multidimensional poverty. Journal of Economic Inequality, 1, 25-49.

Chambers, R. (1997). Whose Reality Counts? Putting the first last, (London: Intermediate Technology).

Davis, P. and B. Baulch (2011). Parallel Realities: Exploring poverty dynamics using mixed methods in rural Bangladesh. Journal of development studies. 47(1):118-142.

Dercon, S. and P. Krishnan (2000). Vulnerability, seasonality and poverty in Ethiopia. Journal of Development Studies 36 (6), 25-53.

Dercon, S. and J. Hoddinott (2004). The Ethiopian rural household surveys: Introduction. May 3, 2004.

Dercon, S., Hoddinott, J., and Woldehanna, T. (2005). Shocks and consumption in 15 Ethiopian villages: 1999-2004. Journal of African Economies, 14(4), 559-585. 
Dercon, S., D. O. Gilligan, J. Hoddinott and T. Woldehanna. (2009). The Impact of Agricultural Extension and Roads on Poverty and Consumption Growth in Fifteen Ethiopian Villages. American Journal of Agricultural Economics. 91(4), 1007-1021.

Dercon, S., J. Hoddinott, T. Woldehanna. (2011). Growth and chronic poverty: Evidence from rural communities in Ethiopia. CSAE working paper WPS/2011-18. June 2011.

Devicienti, F. (2003). Estimating poverty persistence in Britain. Working Paper Series No. 1, Center for Employment Studies, Rome, mimeo.

Dinkelman, T. (2004). How household context affects search outcomes of the unemployed in Kwazulu-Natal, South Africa: A panel data analysis. South African Journal of Economics, 72(3), 484-521.

FDRE (2009) Ministry of Education Fact sheets. Available on: http://www.ethiopia.gov.et/English/MOE/Information/Pages/Fact\%20Sheets.aspx Accessed on August 8, 2011.

Fields, G. (1983). Poverty, inequality, and development, Cambridge University Press.

Foster, J., J. Greer, and E. Thorbecke. (1984). Notes and comments: a class of decomposable poverty measures. Econometrica, 52(3), 761-766.

Haddad, L. and A. Ahmed (2002). Chronic and transitory poverty: evidence from Egypt, 1997-99. World Development, 31(1), 71-85.

Hulme, D. and A. Shepherd (2003). Conceptualizing chronic poverty. World Development, 31(3), 403-423.

Jacoby, H. and E. Skoufias (1992). Risk, Seasonality, and School Attendance. University of Rochester.

Jalan, J. and M. Ravallion (2000). Is Transient poverty different? Evidence from rural China. Journal of Development Studies, 36(6), 82-98.

Kochar, A. (1995). Explaining household vulnerability to idiosyncratic income shocks. AEA Papers and Proceedings. American Economic Review, 85(2), 159-164. 
Laderchi, C. R., R. Saith, F. Stewart (2003). Does it matter that we do not agree on the definition of poverty? A comparison of four approaches. Oxford Development Studies, 31(3): 243-274.

Mckay, A. and Lawson, D. (2003). Assessing the extent and nature of chronic poverty in low income countries: issues and evidence. World Development, 31(3), 425-439.

MoFED (2005). Ethiopia participatory poverty assessment 2004-05. Ministry of Finance and Economic Development (MoFED), Addis Ababa, Ethiopia.

MoFED (2012) Ethiopia's progress towards eradicating poverty: an interim report on poverty analysis study (2011/2012). Development planning and research directorate. Ministry of Finance and Economic Development, Federal Democratic Republic of Ethiopia. March 2012, Addis Ababa. Accessed online: http://www.mofed.gov.et/English/Resources/Documents/Interim $\% 20$ Report $\% 20$ on $\% 202$ 010-11\%20Poverty\%20Analysis.pdf. Accessed on August 12, 2012.

Ravallion, M. (1991). Reaching the Rural Poor Through Public Employment: Arguments, Evidence and Lessons from South Asia. World Bank Research Observer, Vol.6, No.2, pp.153-75. Ravallion, M. (1988). Expected poverty under risk-induced welfare variability. The Economic Journal, 98, 1171-1182.

Sahn, D.E. and D.C. Stifel (2000). Poverty comparisons over time and across countries in Africa. World Development 28(12): 2123-2155.

Sen, A. (1976). Poverty: an ordinal approach to measurement. Econometrica, 44, 219-231.

Sen, A. (1981). Poverty and famines: An essay on entitlement and deprivation. Oxford University Press.

Sen, A. (1985). Commodities and capabilities. Amsterdam: North-Holland.

Sen, A. (1996). On the foundations of welfare economics: Utility, capability and practical reason. In Farina, F., Hahn, F. and Vannucci, S. (eds), Ethics, Rationality and Economic Behaviour. Oxford: Clarendon Press.

Stevens, A. H. (1999). The dynamics of poverty spells: Updating Bane and Ellwood. Journal of Human Resources, 34(3), 557-588. 
Stewart, F., Saith, R. and Harris-White, B. (2007). Defining Poverty in the Developing World. Palgrave Macmillan, London.

Swanepoel, C. (2005). Poverty and poverty dynamics in rural Ethiopia. Stellenbosch Economic Working Papers 3/2005, University of Stellenbosch.

Wooldridge, J. M. (2002). Econometric analysis of Cross Section and Panel Data. Cambridge, Mass.; London: MIT Press.

World Bank (2001). Risk management in South Asia: A poverty focused approach report No. 23509-SAS (Washington, DC. World Bank).

World Bank (2006). Managing water resources to maximize sustainable growth: A country water resources assistance strategy for Ethiopia. Washington D.C.: World Bank. 


\section{Appendix}

Appendix 1. Distribution of deprivation counts in rural Ethiopia (1994-2009)

\begin{tabular}{lllllll}
\hline $\begin{array}{l}\text { Number of } \\
\text { deprivations }\end{array}$ & \multicolumn{2}{c}{$\mathbf{1 9 9 4}$} & \multicolumn{2}{c}{$\mathbf{2 0 0 4}$} & \multicolumn{2}{c}{$\mathbf{2 0 0 9}$} \\
\cline { 2 - 7 } & $\begin{array}{l}\text { Number of } \\
\text { households }\end{array}$ & $\begin{array}{l}\text { \% of } \\
\text { households }\end{array}$ & $\begin{array}{l}\text { Number of } \\
\text { household }\end{array}$ & $\begin{array}{l}\text { \% of } \\
\text { households }\end{array}$ & $\begin{array}{l}\text { Number of } \\
\text { households }\end{array}$ & $\begin{array}{l}\text { \% of } \\
\text { households }\end{array}$ \\
\hline 0 & 5 & 0.48 & 11 & 1.05 & 36 & 3.45 \\
1 & 40 & 3.38 & 72 & 6.90 & 174 & 16.67 \\
2 & 120 & 11.49 & 236 & 22.61 & 366 & 35.06 \\
3 & 262 & 25.10 & 329 & 31.51 & 319 & 30.56 \\
4 & 318 & 30.46 & 252 & 24.14 & 130 & 12.45 \\
5 & 236 & 22.61 & 119 & 11.40 & 19 & 1.82 \\
6 & 60 & 5.75 & 23 & 2.20 & 0 & 0 \\
7 & 3 & 0.29 & 2 & 0.19 & 0 & 0 \\
\hline $\mathrm{N}$ & 1044 & 100 & 1044 & 100 & 1044 & 100 \\
\hline
\end{tabular}

Appendix 2. Test of independence for MPI indicators (Pearson Chi2 probability values)

\begin{tabular}{|c|c|c|c|c|c|c|c|c|}
\hline & $\begin{array}{l}\text { Child } \\
\text { mortality }\end{array}$ & Morbidity & $\begin{array}{l}\text { Child } \\
\text { enrollment }\end{array}$ & $\begin{array}{l}\text { Years of } \\
\text { schooling }\end{array}$ & Assets & Housing & $\begin{array}{l}\text { Drinking } \\
\text { water }\end{array}$ & Year \\
\hline \multirow{3}{*}{ Child mortality } & 0.000 & 0.350 & 0.014 & 0.511 & 0.170 & 0.788 & 0.429 & 1994 \\
\hline & 0.000 & 0.143 & 0.145 & 0.140 & 0.875 & 0.858 & 0.719 & 2004 \\
\hline & 0.000 & 0.312 & 0.104 & 0.322 & 0.193 & 0.435 & 0.223 & 2009 \\
\hline \multirow[t]{3}{*}{ Morbidity } & & 0.000 & 0.224 & 0.000 & 0.342 & 0.381 & 0.016 & 1994 \\
\hline & & 0.000 & 0.249 & 0.228 & 0.456 & 0.030 & 0.015 & 2004 \\
\hline & & 0.000 & 0.282 & 0.927 & 0.405 & 0.641 & 0.002 & 2009 \\
\hline \multirow{3}{*}{$\begin{array}{l}\text { Child } \\
\text { enrollment }\end{array}$} & & & 0.000 & 0.072 & 0.080 & 0.372 & 0.737 & 1994 \\
\hline & & & 0.000 & 0.000 & 0.981 & 0.040 & 0.089 & 2004 \\
\hline & & & 0.000 & 0.002 & 0.914 & 0.317 & 0.019 & 2009 \\
\hline \multirow{3}{*}{$\begin{array}{l}\text { Years of } \\
\text { schooling }\end{array}$} & & & & 0.000 & 0.270 & 0.675 & 0.147 & 1994 \\
\hline & & & & 0.000 & 0.000 & 0.047 & 0.823 & 2004 \\
\hline & & & & 0.000 & 0.122 & 0.374 & 0.133 & 2009 \\
\hline \multirow[t]{3}{*}{ Assets } & & & & & 0.000 & 0.000 & 0.502 & 1994 \\
\hline & & & & & 0.000 & 0.000 & 0.001 & 2004 \\
\hline & & & & & 0.000 & 0.002 & 0.065 & 2009 \\
\hline \multirow[t]{3}{*}{ Housing } & & & & & & 0.000 & 0.000 & 1994 \\
\hline & & & & & & 0.000 & 0.389 & 2004 \\
\hline & & & & & & 0.000 & 0.000 & 2009 \\
\hline \multirow{3}{*}{$\begin{array}{l}\text { Drinking } \\
\text { water }\end{array}$} & & & & & & & 0.000 & 1994 \\
\hline & & & & & & & 0.000 & 2004 \\
\hline & & & & & & & 0.000 & 2009 \\
\hline
\end{tabular}


Appendix 3. Adjusted head count ratio (Mo) using nested weights (1994-2009)

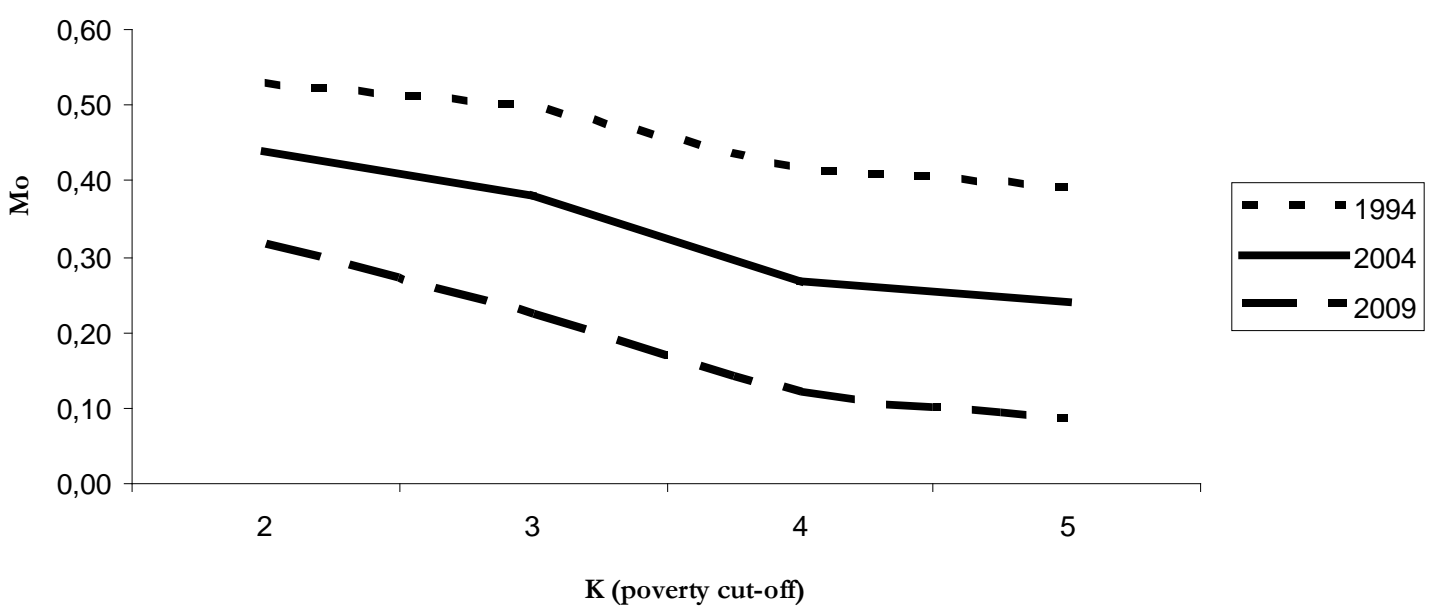

Appendix 4. Trends in poverty $(1995 / 96-2010 / 11)$ head count ratio

\begin{tabular}{llll}
\hline & National & Rural & Urban \\
\hline $1995 / 1996$ & 0.455 & 0.475 & 0.332 \\
$1999 / 2000$ & 0.442 & 0.454 & 0.369 \\
$2004 / 2005$ & 0.387 & 0.393 & 0.351 \\
$2010 / 2011$ & 0.296 & 0.304 & 0.257 \\
\hline
\end{tabular}

Source: MoFED (2012) 